\title{
Assessment peculiarities of loan obligations for enterprises of investment and construction complex in the context of economy digitalization
}

\author{
Evgenia Grigorash ${ }^{1}$, Sofiya Samodurova ${ }^{1, *}$, Vladimir Grigorash ${ }^{1}$, and Maksat Redzhepov ${ }^{1}$ \\ ${ }^{1}$ Voronezh State Technical University, Moscow Avenue, 14, Voronezh, 394026, Russia
}

\begin{abstract}
The article deals with the procedure for assessing the market value of loan obligations for enterprises of the investment and construction complex in the context of the digitalization of the Russian economy. The relevance of the topic is confirmed by the fact that digital systems and technologies have been developing rapidly in Russia in recent years, since the level of development of the digital economy is important for increasing the competitiveness of the state with other developed countries. The banking system is inextricably linked with the digital economy, which completely changes the structure of the banking system as a whole, first of all, accelerating all processes, making them more accessible and transparent. The authors of the article study the concept of a digital economy and examine the impact of the digital economy on the banking system. Assessment of the market value of loan obligations in business is a new topic in appraisal activities. The article discusses in detail the approaches to determining the market value of a business, the most suitable methods for determining the market value of a right of claim are clarified and updated. The authors investigated the concept of a collection agency, the procedure for cooperation between credit institutions and agencies. They analyze the statistics on the sale of debts, as well as the advantages for credit institutions of transferring the right of claim to agencies.
\end{abstract}

\section{Introduction}

Recently, the digital economy and IT technologies have begun to develop rapidly in Russia. These circumstances become necessary to increase the competitive advantage of investment and construction enterprises complex, both in the external and internal markets, introducing digital technologies for the implementation of business transactions, which to a greater extent allows them to increase productivity. At the same time, the state actively supports the introduction of digitalization into the production activities of enterprises, including through support in the form of benefits, subsidies, etc. Digitalization is not the least of all in the banking system. [4]

For enterprises of the investment and construction complex, the use of borrowed funds is becoming an essential condition for running a successful business. The need for loans for

\footnotetext{
${ }^{*}$ Corresponding author: sofiya.samodurova@mail.ru
} 
enterprises in the construction industry is explained by the high costs for their production activities. It should be noted that when lending, the risks of not repaying the loan arise not only from the borrower, but also from the lender - the bank. [14]

When securing a loan, various risks arise associated with the depreciation of the debt, damage to the subject of debt, or the loss of some of its main properties, non-liquidity, in other words, non-sale of the debt. [10]

Quite often there is a transfer of the obligation to repay the loan to other (third) parties, if their ownership is registered.

In Article. 336 of the Civil Code, it is said that absolutely any property, as well as property rights (Article 128 of the Civil Code) can be the subject of pledge [1].

The size of the pledged obligations is regulated by the rules of law, it is fixed in the agreement or the market value of the property acting as a pledge is determined (Article 337 of the Civil Code) [1]. Moreover, it should be safe and almost in its original form for a long period of time until the cost of the loan is paid.

Purpose of the study is to analyze the methodology for determining the market value of credit obligations (rights of claim) for enterprises of the investment and construction industry in the context of economy digitalization.

\section{The material and methods of research}

The digital economy is a system of economic relations based on the use of digital information and communication technologies, the banking system is not least of all in this. [2] The banking system is inextricably linked with the digital economy, which completely changes the structure of the banking system as a whole, first of all, by speeding up all processes, making them more accessible and translucent.

In 2020 competition in the payment claims market is increasing, thereby provoking an increase in the volume of overdue loans in the Russian debt market. Competition in the debt market is increasing due to the emergence of digital technologies in the economy, modern banking products, and the ever-increasing possibilities in digital loan approval procedures. [6]

In the modern economy we see an upswing in digitalization of the banking system. Essentially, it is the transfer of most processes working with banking products into a digital system. A lot of transactions are performed remotely; this includes contactless payments, payment requests, and other banking products.

Recently, since the acceleration in digitalization of the economy and, as a result, of the banking system, the profitability of the latter has increased approximately by 4 times. This happened, first of all, due to the rapid introduction of digital technologies, as well as the transfer of employees to remote work, which allows optimizing costs and urgently implementing a high level of business intelligence. As a result, the number of branches has decreased significantly. All banking processes, if desired, can be brought to a remote level, saving at least the rent and salaries of employees. [7]

In some cases, there is a reverse trend - when digital banks open real offices, explaining this by the desire to enter a new category and cover an unreached segment, for example, the category of elderly people. Thanks to digital technologies, new formats of banking products not only for business but also for individuals are emerging. [9]

The digital transformation of the banking system provides flexibility in work and the ability to move and develop at an accelerated pace. The tasks of digitalization should be built in systematically and within one single platform, which will allow them to be more accessible and secure.

Classically, for the assessment, regardless of the object category, as well as for the assessment of credit liabilities, three approaches are used: profitable, costly and comparative. 
Russian legislation regulates the process of assessing the right to claim in the modern digital economy.

Each of the applied approaches is fundamentally different from the others, and is based on crucially different methods, that is why they should be used in summation, since, in this way, the most real result of the object market value (in our case, the right of claim) is provided (Table 1) [3].

The profitable approach is quite often used when evaluating business, credit obligations, securities, because it is able to reflect the essence of investments, that is, the ability to bring money in time. The profitable approach takes into account the time factor and brings future cash flows, distributed over the years, to the current price level. All stable and unstable situations connected with investments that occur in the surrounding plane (in other words, they are called risks) are taken into account. The very process of bringing investments to the current price level is called discounting.

In the classic situation of debt arising, there is an assessment of the property of the pledge and guarantors, which is the insurance of the payment claim and is potentially intended to repay the debt (Article 363 of the Civil Code of the Russian Federation). [1]

When assessing the rights of claims, taking into account the existing legislation, it is assumed that the use of comparative and costly approaches will be abandoned due to the lack of reliable information and the poverty of its quantity, as well as the lack of interest in the issue of debt formation.

Table 1. Methods of business appraisal.

\begin{tabular}{|c|c|c|}
\hline \multicolumn{3}{|c|}{ METHODS OF BUSINESS APPRAISAL } \\
\hline $\begin{array}{l}\text { COSTLY } \\
\quad \text { PV = PS }+ \text { PP } \\
\text { - PV - market value of a } \\
\text { company } \\
\text { - PS - cost of land } \\
\text { - PP - cost of object } \\
\text { reproduction }\end{array}$ & $\begin{array}{l}\text { COMPARATIVE SALES } \\
\text { ANALYSIS } \\
\qquad \text { PV }=\mathbf{S}+\text { ADI } \\
\text { - S - comparable selling } \\
\text { price } \\
\text { - ADI - monetary expression } \\
\text { of the cumulative adjustment } \\
\text { to the selling price }\end{array}$ & $\begin{array}{c}\text { PROFITABLE } \\
\text { PV }=\text { Y / R } \\
\text { - Y - future income } \\
\text { - R - capitalization rate }\end{array}$ \\
\hline $\begin{array}{l}\text { It is used when it is } \\
\text { impossible to estimate } \\
\text { income and there is no } \\
\text { market information. }\end{array}$ & $\begin{array}{l}\text { The restriction of its use is } \\
\text { lack of information about } \\
\text { the market infrastructure. }\end{array}$ & $\begin{array}{l}\text { It is used when income is } \\
\text { stable. }\end{array}$ \\
\hline
\end{tabular}

The use of the profitable approach allows the most reliably assess the payment request cost, taking into account all the necessary data available for this on both the income and expenditure parts. The determination of the market value is based on the liquidity of the product (payment request). [12]

When involving a judicial authority to resolve a dispute in the absence of payments and the occurrence of loan debt, the market value of rights (of claims) is determined as the sum of discounted flows from the financial and economic activities of all parties: the debtor, 
sureties, guarantors, as well as from the sale of pledged items, taking into account the procedure, timing of collection and implementation of associated costs. [11]

In the appraisal practice, there is no methodology for assessing the market value of the right of claim, but in the case under review, the authors found two most suitable strategies for calculating the market value of a loan product - a payment request. [15]

Strategy 1: method for assessing the value of interest-bearing liabilities, model CAPM;

Strategy 2: the method of capital assets in the modified MCAPM model. 1.

The estimate of the current value of the payment request is calculated using the formula

$$
Y=\sum_{t=1}^{n} \frac{i \cdot X}{(1+g)^{t}}+\frac{X}{(1+g)^{n}}
$$

where

$\mathrm{Y}$ - current loan coat at the date of assessment,

$\mathrm{X}$ - balance of the loan at the date of assessment,

$\mathrm{n}$ - number of periods until loan repayment,

$\mathrm{i}$ - adjusted lending rate of interest under the agreement for the period (the lending rate in shares divided by 12),

$\mathrm{g}$ - average market lending rate for the period (the lending rate in shares divided by 12).

The calculation of the payment request cost with a ball payment of the principal amount is performed using the compound interest function (Formula 2):

$$
Y=X \cdot f_{n}(i, g) \text {, }
$$

$f \mathrm{n}(\mathrm{i} . \mathrm{g})$ is a function defined by the formula 3 :

$$
f_{n}(i, g)=\frac{i}{g} \cdot\left(1-(1+g)^{-n}\right)+(1+g)^{-n} \text {. }
$$

In particular, if the value of the rate on the payment request coincides with the value of the market rate $\mathrm{I}=\mathrm{g}$, then it follows from formula (3) that the market value of the payment request is equal to the nominal $\mathrm{Y}=\mathrm{X}$.

The second way is the MCAPM model. At the bottom of its calculations are data based on real market information at the current time or on the date of assessment.

The point of the considered methods is to use suitable approaches to calculate the discount rate (Formula 4):

$$
\mathrm{R}=\mathrm{R}_{\mathrm{f}}+\beta^{*}\left(\mathrm{R}_{\mathrm{m}}-\mathrm{R}_{\mathrm{f}}\right)+\mathrm{S} \mathrm{M}+\mathrm{S \kappa}
$$

where

$\mathrm{R}$ - discount rate;

$\mathrm{Rf}$ - rate of return on safe investments with a bank guarantee, regulated by the state, as a rule, equal to the refinancing rate;

$\mathrm{Rm}$ - average market discount rate, as a rule, is determined on the basis of data on average rates;

$\beta$ - beta coefficient, which measures the recurring risk;

$\mathrm{Sm}-$ premium for the scale of the organization (when it decreases, there is an increase in risks);

$\mathrm{SK}$ - coefficient that takes into account the riskiness of investments.

On the basis of the discount rate, the discount coefficient is calculated, which will show the amount of profit that the company will receive after $-n$ number of years, but in current value terms (Formula 5): 


$$
\mathrm{P}=1 /(1+\text { Discount rate })^{\mathrm{n}}
$$

The discount rate is influenced by a number of factors [8]:

- solvency, financial stability and creditworthiness;

- quality of return on attracted investments;

- the environment, the world economy as a whole, the economy of a particular region, the political situation;

- the ratio of the organization's own and borrowed funds when financing projects.

\section{Research results and their discussion}

Digital technologies have allowed banks to gain a competitive edge and become more profitable than ever before. First of all, digital technologies have allowed loan products to turnover better. [13]

The greatest attention of banks is directed to overdue claims. To speed up the process of turnover and repayment of debts, banks attract third-party organizations (agencies) from the moment of delays in payments.

When selling the right of claim on the open market, the price at which this object is sold, as a rule, is its market value, but only if the amount of the transaction value is not influenced by external factors and all the necessary information is transparent for all parties of the transaction.

An agency providing collection services is an organization that collects problem loans in the pre-trial and judicial order.

As a rule, most of them work on the part of the creditors, buying debts from them, thus repaying debts for a certain fee, a pre-agreed percentage of the total collected amount. There is an option to buy out the entire debt from the bank under a cession agreement.

With the use of digital technologies, the efficiency of collection agencies has increased by $30 \%$. [7]

Large organizations act as creditors. The difference between the amount that can be returned and the total amount of debt in this case is a loss.

Professional agencies that bought the debt try to return it at the beginning of the debt formation, which makes it possible to resolve the conflict with less difficulty.

There is another variant of the debt agency's work, in which it works with the lender without concluding a formal agreement on the repurchase of the loan. But the essence remains the same, the only difference is that under this scheme, the debtor continues to make payments on the loan.

The amount of the collection agency's remuneration depends, to a greater extent, on the degree and speed of debt collection, and also takes into account penalties, fines, and so on.

Remuneration to collectors is approximately $15 \%-30 \%$ from the amount of repaid debts.

The amount of remuneration depends on the amount of debt, its type, often on the term of the debt and averages $25 \%$.

In most cases, collectors return about $85 \%$ of the total debt, with the majority of collectors' fees.

The total amount of debt that collectors buy from banks has been growing steadily over the past few years. Over the past two years, this figure has grown by 30 percent; this is due to the fact that loans are serviced worse. For banks, this situation creates many problems, a large number of loans lose quality and acquire the status of "overdue". This problem arises, first of all, due to the dependence of borrowers on official income, that is, it is significantly less than loan payments, consisting of the principal amount plus interest on it. Unfortunately, the statistics on debts provided by the Central Bank of the Russian Federation takes into account only overdue loans, therefore, it is not complete. 
According to collectors, the amount of problem loans by mid-2020 is more than 800 billion rubles. [5]

The most widespread, fairly cheap and fast way of communicating with the debtor is Telephony, that is, telephone calls. They are used by collectors at the beginning of the collection process, which is the easiest and most loyal way to communicate with the debtor, compared to the rest. This became possible with the development of the digital economy. We can say that this is a separate segment of the digital economy. This also includes sending messages, as well as notifications about the presence of debt and overdue debt as well. At the very beginning, the debtors are informed about their obligations to pay the debt and the motivation for the fact of payment is soft. The legislation of the country in which the debt agency is located regulates the actions of the latter.

The debt agency has the right and opportunity, thanks to the development of the digital economy, to collect information about the debtor to speed up the debt collection process, as well as collect personal information and personal data about the debtor that were not previously disclosed by the debtor and were not provided during the loan process.

The cost of the right to claim depends on the loan itself. The market value of credit debt, in other words, the right to claim, ranges from zero to the whole amount of the loan.

The amount of the right to claim is determined by the following factors:

- the size of the loan at date of assessment;

- the possibility and cost of covering the right of claim;

- the presence of various risks, etc.

With the growth of the digitalization of the economy, there are many more opportunities for debt repayment, as well as guarantees that due to the implementation of an overdue loan, the bank will be able to fully cover its costs. Banks could not provide these guarantees earlier.

Hiring professional collectors is costly and time consuming.

The state duty dictates the formation of the amount of legal costs (Article 333.21 of the Tax Code of the Russian Federation).

Table 2. summarizes the debt-related discount factor.

\begin{tabular}{|c|c|}
\hline Debt term & Collectors' rate \\
\hline Up to ninety days & Do not work \\
\hline Ninety - one hundred and eighty days & Do not work \\
\hline $\begin{array}{c}\text { One hundred and eighty - two hundred } \\
\text { and seventy days }\end{array}$ & Do not work \\
\hline $\begin{array}{c}\text { Two hundred and seventy - three } \\
\text { hundred and sixty days }\end{array}$ & From 2 to $8 \%$ \\
\hline $\begin{array}{c}\text { Three hundred and sixty - seven } 1.5 \text { to } 5 \% \\
\text { hundred and twenty days }\end{array}$ & From 1 to $3.6 \%$ \\
\hline $\begin{array}{c}\text { Seven hundred and twenty - one } \\
\text { thousand and eighty days }\end{array}$ & From 0.5 to $3.2 \%$ \\
\hline More than one thousand and eighty days & From $0.1 \%$ \\
\hline Problematic loans & Up to $5 \%$ \\
\hline Bad loans &
\end{tabular}

Cooperation between debt and banking structures occurs according to the following principles. When a bank transfers debt obligations for outsourcing, the amount of remuneration to a debt organization is, in practice, up to $30 \%$ on debts with delays of up to two months, up to $70 \%$ - for longer ones. In some cases, the cost of services of a collection 
organization reaches $95 \%$ and depends on the amount of debt to be collected - the loan portfolio. All this becomes possible thanks to the digitalization of the economy.

The transfer of claims from the bank's balance sheet to the balance sheet of collection organizations has the following advantages for banking structures:

1. The cost of remuneration to collection organizations is not paid in advance.

2. Removal of overdue debts from the bank's balance sheet leads to tax optimization.

3. It is not necessary to create an internal body to work with debtors, therefore, there is a saving on these costs.

4. When writing off the bank's debts to collection organizations, the reputation of banking structures does not suffer.

\section{Conclusions}

The introduction of the digital economy into the economic system of Russia is a new stage in the development of all sectors of the national economy.

Digitalization of the banking system completely changes it, first of all, speeding up all processes, making them more accessible and transparent. Digital technology has allowed banks to gain a competitive edge and become more profitable than ever before. First of all, digital technologies have allowed loan products to turnover better.

The analysis of the market for rights of claims in the context of the digitalization of the Russian economy, it allows us to draw certain conclusions.

The timely transfer of all banking processes, including the assessment of loan obligations, to the digital system helped to increase banks' repayment of overdue debts, including those classified as problematic and bad.

Securities prevail on the credit market of the Russian Federation, since corporate rights of claim are not issued for circulation on the market, but are put up for sale only due to the impossibility of collecting the debt with the own funds.

Securities are issued to attract loans, first of all, the profitability of securities directly depends on the reliability of the loan and its liquidity.

The yield obtained from securities is about 10 percent per annum.

The yield on low liquid bonds and bills of non-credit institutions is around 15 percent.

The return on investment of rights of claim is calculated in hundreds of percent, since their acquisition is associated with highly probable risks of loss of invested funds.

\section{References}

1. http://www.consultant.ru/document/cons_doc_LAW_5142/(Last accessed 12.01.2021)

2. Rasporyazheniye Pravitel'stva RF 28.07.2017 № 1632 ob utverzhdenii Programmy «Tsifrovaya ekonomika Rossiyskoy Federatsii».

3. E. V. Grigorash, S. A. Samodurova, L. P. Myshovskaya, V. V. Grigorash, Osobennosti otsenki prava trebovaniya na sovremennom etape. Vestnik Altayskoy akademii ekonomiki i prava, 4-1, 36-43, (2020) https://vaael.ru/ru/article/view?id=1052 (Last accessed 12.01.2021)

4. https://elibrary.ru/item.asp?id=35353174 (Last accessed 15.01.2021)

5. V. V. Denisova, L. V. Kamdina, Upravleniye prosrochennoy kreditorskoy zadolzhennost'yu. Tsifrovaya ekonomika v sotsial'no-ekonomicheskom razvitii Rossii: vzglyad molodykh, Ural'skiy filial Finuniversiteta 106-108 (2019)

6. D. A. Dukhovnykh, M. S. Agafonova, Problemy i riski formirovaniya i razvitiya tsifrovoy ekonomiki v Rossii, European Journal of Natural History, 1, 110-114 (2020) 
7. V. V. Kiselev, Kommercheskiye banki v Rossii: nastoyashcheye i budushcheye (Bankovskaya politika. Regulirovaniye i upravleniye) 876 (2017)

8. V. I. Kolesnikova, Bankovskoye delo. Finansy i statistika, 243 (2016)

9. V. S. Kudryashov, Internet-banking v Rossiyskoy Federatsii: problemy i perspektivy razvitiya, Ekonomicheskiye nauki. 4, 27-31 (2017)

10. O. A. Kutsygina, Ye. M. Tverdokhlebova, Riski ispol'zovaniya bankovskogo kredita kak osnovnogo istochnika zayemnykh sredstv predpriyatiy, Ekonomika i upravleniye narodnym khozyaystvom, 24-29 (2018)

11. http://srosovet.ru/activities/Metod/ (Last accessed 17.01.2021)

12. http:/ https://srosovet.ru/activities/Metod/method_r/mr_zadolgennost/ (Last accessed 17.01.2021)

13. V. V. Popov, Internet-banking. Rossiyskiy rynok distantsionnogo bankovskogo obsluzhivaniya / Perspektivy razvitiya informatsionnykh tekhnologiy, 29, 78-82 (2016)

14. I. A. Provotorov, A.V. Vtornikov, Aktual'nyye napravleniya tsifrovizatsii stroitel'noy otrasli // Tsifrovaya i otraslevaya ekonomika, 2(19), 126-129 (2020)

15. https://www.cfin.ru/appraisal/business/special/chose_in_action.shtml (Last accessed 17.01.2021) 